\title{
ARTIKEL \\ ANALISIS PENGGUNAAN KOHESI LEKSIKAL PADA TEKS EKSPOSISI SISWA KELAS X SMKN 2 MEDAN TAHUN \\ PEMBELAJARAN 2016/2017
}

Oleh

Megawati Sinurat

NIM 2133311058

Dosen Pembimbing Skripsi

Dr. Syahnan Daulay, M. Pd.

Telah Diverifikasi dan Dinyatakan Memenuhi Syarat untuk Diunggah pada Jurnal Online

Editor,

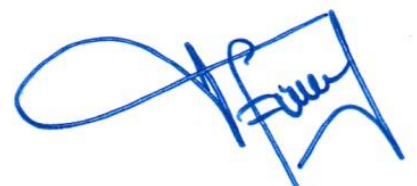

Fitriani Lubis, S.Pd., M.Pd. NIP 197708312008122001
Medan, Agustus 2017

Menyetujui :

Dosen Pembimbing Skripsi,

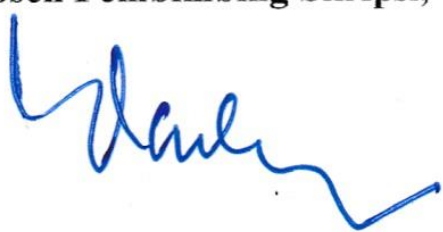

Dr. Syahnan Daulay, M. Pd. NIP 195808311986011002 


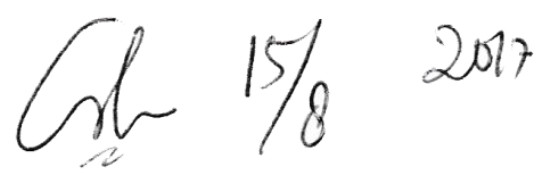

\title{
ANALISIS PENGGUNAAN KOHESI LEKSIKAL PADA TEKS EKSPOSISI SISWA KELAS X SMKN 2 MEDAN TAHUN PEMBELAJARAN 2016/2017
}

\author{
Oleh \\ Megawati Sinurat \\ Dr. Syahnan Daulay, M. Pd.
}

\begin{abstract}
ABSTRAK
Penelitian ini bertujuan untuk mengetahui penggunaan kohesi leksikal pada teks eksposisi siswa kelas X SMKN 2 Medan tahun pembelajaran 2016/2017. Penelitian ini menggunakan sumber data yaitu sebanyak 32 teks eksposisi siswa kelas X. Metode yang digunakan dalam penelitian ini adalah metode deskriptif kualitatif. Instrumen yang digunakan adalah peneliti sendiri. Metode deskriptif kualitatif ini sering disebut non eksperimen, karena pada penelitian ini peneliti tidak melakukan kontrol manipulasi variabel penelitian. Hasil menunjukkan ditemukan penggunaan kohesi leksikal pada teks eksposisi siswa kelas X SMKN 2 Medan tahun pembelajaran 2016/2017 berjumlah 130 yang terdiri dari repetisi, sinonim, antonim, hiponim, kolokasi dan ekuivalensi. Penggunaan kohesi leksikal dalam teks eksposisi siswa kelas X SMKN 2 Medan Tahun Pembelajaran 2016/2017 terdiri dari repetisi berjumlah $38,46 \%$ atau 50 dari 130, sinonim berjumlah $11,54 \%$ atau 15 dari 130, antonim berjumlah $10,77 \%$ atau 14 dari 130, hiponim berjumlah $2,31 \%$ atau 3 dari 130, kolokasi berjumlah 20,77\% atau 27 dari 130, dan ekuivalensi berjumlah $16,15 \%$ atau 21 dari 130 jumlah keseluruhan penggunaan kohesi leksikal. Penggunaan kohesi leksikal terdiri dari ketepatan penggunaan repetisi 88,41\% atau 154 dari 130 jumlah keseluruhan kohesi leksikal dan ketidaktepatan kohesi leksikal terdiri dari repetisi, hiponim, kolokasi dan ekuivalensi dengan jumlah $11,59 \%$ atau 19 dari 130 jumlah keseluruhan penggunaan kohesi leksikal. Dari data kualitatif tersebut, ketepatan penggunaan kohesi leksikal pada teks eksposisi siswa kelas X SMKN 2 Medan termasuk dalam kategori Sangat Baik. Penggunaan kohesi leksikal dalam teks eksposisi siswa kelas X SMKN 2 Medan tahun pembelajaran 2016/2017 yang paling dominan adalah repetisi (pengulangan) dengan jumlah persentase 38,46\% atau 50 dari 130 dan penggunaan kohesi leksikal pada teks eksposisi siswa kelas X SMKN 2 Medan yang paling sedikit digunakan adalah hiponim dengan jumlah persentase 2,31\% atau 3 dari 130 penggunaan kohesi leksikal.
\end{abstract}

Kata kunci: Kohesi Leksikal, Ketepatan, Ketidaktepatan, Teks Eksposisi 


\section{PENDAHULUAN}

Penguasaan kemampuan berbahasa Indonesia sangat penting sebagai alat komunikasi, baik secara lisan maupun tulisan. Kemampuan berbahasa ini harus dibinakan dan dikembangkan sejak dini kepada siswa. Salah satu wujud pembinaan kemampuan siswa dalam berbahasa adalah dengan menerapkan pengajaran bahasa di tingkat SD, SMP, SMA/ SMK, dan Perguruan Tinggi. Pembelajaran bahasa khususnya bahasa Indonesia di SMA/ SMK memiliki tujuan agar siswa dapat mengembangkan kemampuan berkomunikasi. Untuk dapat menguasai kemampuan berkomunikasi, Mata Pelajaran bahasa Indonesia dibagi menjadi empat aspek yang harus dikuasai oleh siswa, yaitu membaca, mendengarkan atau menyimak, berbicara, dan menulis. Di antara empat aspek pelajaran bahasa Indonesia terdapat dua aspek yang bersifat aktif. Dua aspek tersebut adalah membaca dan menulis. Membaca dan menulis merupakan keterampilan berbahasa aktif yang sangat penting untuk dikuasai oleh siswa. Karena dengan menguasai dua aspek tersebut, siswa dapat mengembangkan keterampilan yang dapat bermanfaat bagi masa depan. Dari dua keterampilan aktif berbahasa, menulis merupakan satu keterampilan yang penting untuk dikuasai. Suatu teks yang padu adalah teks yang apabila dilihat dari segi hubungan bentuk atau struktur lahir bersifat kohesif dan dilihat dari segi hubungan makna atau struktur batinnya bersifat koheren. Suatu teks dikatakan utuh apabila kalimat-kalimat dalam teks itu mendukung satu topik yang sedang dibicarakan, sedangkan wacana dikatakan padu apabila kalimat kalimatnya disusun secara teratur dan sistematis, sehingga menunjukkan keruntutan ide yang diungkapkan melalui penanda kekohesian.

Dari uraian di atas, jelas bahwa aspek-aspek yang membentuk kohesi di dalam teks harus berkesinambungan dan membentuk kesatuan struktur teks agar dapat mendukung koherensi. Apabila urutan progresi pada suatu teks tidak jelas maka akan menyebabkan ambigu dan tidak koherennya suatu teks. Suatu ujaran yang tidak jelas urutan awal, tengah dan akhir bukan merupakan teks yang baik.

Sanggup Barus (2010:1) mengemukakan "Menulis adalah rangkaian kegiatan mengungkapkan dan menyampaikan gagasan atau pikiran dengan bahasa tulis kepada pembaca sehingga pembaca dapat memahaminya.” Istilah kohesi pertama kali diperkenalkan oleh Halliday dan Hasan pada tahun 1976. Kohesi merupakan sebuah istilah dalam teks linguistik yang diwujudkan dalam teks gramatik. Kohesi berasal dari bahasa Latin cohaerere yang memiliki pengertian sama dengan zusammenstecken dan zusammenschaften. Kohesi merujuk pada fungsi sintaksis dalam sebuah teks atau sebuah komunikasi. 
Sumarlam (2003:35) mengatakan "Kohesi leksikal adalah hubungan antar unsur dalam wacana secara sistematis." Dalam hal ini, untuk menghasilkan wacana yang padu pembicara atau penulis dapat menempuhnya dengan memilih kata-kata yang sesuai dengan isi kewacanaan yang dimaksud. Hubungan kohesi yang diciptakan atas dasar aspek leksikal, dengan pilihan kata yang serasi, menyatakan hubungan makna atau relasi semantik antar satuan libgual yang satu dengan satuan lingual yang lain dalam wacana.

Mahsun (2013:31) mengemukakan “Teks eksposisi adalah paparan gagasan atau ususlan sesuatu yang bersifat pribadi atau sering disebut dengan teks argumentasi satu sisi, struktur berpikir yang sering menjadi muatan teks eksposisi adalah tesis atau pernyataan pendapat alasan dan argumentasi, dan pernyataan ulang pendapat." Eksposisi (paparan) adalah suatu bentuk penulisan yang menjelaskan atau menguraikan sehingga pembaca atau pendengar dapat memahami masalah itu.

Dari hasil pengamatan yang saya lakukan selama PPLT saya melihat kemampuan siswa SMKN 2 Medan dalam menulis karangan eksposisi masih rendah hal itu dilihat dari hasil penilaian guru terhadap hasil karangan teks eksposisi siswa masih banyak yang rendah dan masih di bawah KKM, selain itu pemahaman siswa mengenai kohesi leksikal masih kurang hal itu dilihat dari pada saat guru memberikan tugas kepada siswa untuk mencari kohesi leksikal yaitu bagian repetisi, sinonim, antonim, hiponim, kolokasi dan ekuivalensi siswa masih banyak yang nilainya rendah. Selain itu, karena karangan teks eksposisi berisi paparan gagasan atau usulan sesuatu yang berasal dari pemikiran atau pendapat sendiri sehingga siswa dalam menciptakan karangan eksposisi kurang memperhatikan kohesi leksikal antar kata atau antar kalimat dan antar paragraf dan dan karangan eksposisi banyak mencakup kohesi leksikal sehingga penulis tertarik untuk melakukan analisis penggunaan kohesi leksikal pada teks eksposisi siswa kelas X SMKN 2 Medan.

\section{METODE PENELITIAN}

Metode yang digunakan dalam penelitian ini adalah metode deskriptif kualitatif. Metode deskriptif kualitatif adalah prosedur penelitian berdasarkan data deskriptif, yaitu berupa lisan atau kata tertulis dari seseorang subjek yang telah diamati dan memiliki karakteristik bahwa data yang diberikan merupakan data asli yang tidak diubah serta menggunakan cara yang sistematis dan dapat dipertanggungjawabkan kebenarannya. Syamsuddin (2009:14) mengatakan "penelitian deskriptif kualitatif adalah suatu pendekatan yang juga disebut dengan pendekatan investigasi karena biasanya peneliti mengumpulkan data dengan cara bertatap muka langsung dan berinteraksi dengan orang-orang ditempat penelitian". 
Metode penelitian yang digunakan dalam penelitian ini adalah metode deskriptif kualitatif. Penelitian deskriptif kualitatif ini dilakukan dengan menganalisis teks eksposisi yaitu dengan menganalisis penggunaan kohesi leksikal pada teks eksposisi siswa kelas $\mathrm{X}$ SMKN 2 Medan Tahun Pembelajaran 2016/2017.

\section{HASIL PENELITIAN DAN PEMBAHASAN}

\section{Hasil Penelitian}

\section{Jenis Kohesi Leksikal dalam Teks Eksposisi Siswa SMKN 2 Medan Tahun Pembelajaran 2016/2017}

Jenis Kohesi Leksikal Pada Teks Eksposisi Siswa Kelas X SMKN 2 Medan Tahun pembelajaran 2016/2017 berjumlah 130 yang terdiri dari repetisi, sinonim, antonim, hiponim, kolokasi dan ekuivalensi. Penggunaan tersebut dari ulangan penuh berjumlah 23, ulangan dengan bentuk lain berjumlah 11, ulangan dengan penggantian berjumlah 16 , sinonim mutlak berjumlah 6 , sinonim semirip berjumlah 7 , sinonim selingkung berjumlah 3 , antonim mutlak

berjumlah 4 , antonim kutub berjumlah 6 , antonim hierarkial berjumlah 2 , antonim majemuk berjumlah 2, hiponim berjumlah 3, kolokasi berjumlah 27 dan ekuivalensi berjumlah 21 .

Penggunaan kohesi leksikal pada teks eksposisi siswa kelas X SMKN N 2 Medan terdiri dari repetisi berjumlah $38,46 \%$ atau 50 dari 130 , sinonim berjumlah $11,54 \%$ atau 15 dari 130, antonim berjumlah $10,77 \%$ atau 14 dari 130, hiponim berjumlah 2,31\% atau 3 dari 130, kolokasi berjumlah 20,77\% atau 27 dari 130, dan ekuivalensi berjumlah 16,15\% atau 21 dari 130 jumlah keseluruhan penggunaan kohesi leksikal.

\section{Penggunaan Jenis Kohesi Leksikal dalam Teks Eksposisi Siswa SMKN 2 Medan Tahun Pembelajaran 2016/2017}

Penggunaan kohesi Leksikal pada Teks Eksposisi Siswa Kelas X SMKN 2 Medan Tahun Pembelajaran 2016/2017 terdiri dari ketepatan dan ketidaktepatan. Ketepatan penggunaan kohesi leksikal berjumlah 90,77\% atau 118 dari 130 jumlah keseluruhan kohesi leksikal dan ketidaktepatan berjumlah 9,23\% atau 12 dari 130 jumlah keseluruhan penggunaan kohesi leksikal. Dari data kualitatif tersebut, ketepatan penggunaan kohesi leksikal pada teks eksposisi siswa kelas X SMKN 2 Medan termasuk dalam kategori Sangat Baik. 


\section{Penggunaan Jenis Kohesi Leksikal Yang Paling Dominan Digunakan Dalam Teks Eksposisi Siswa Kelas X SMKN 2 Medan Tahun Pembelajaran 2016/2017}

Berdasarkan hasil penelitian yang telah dilakukan peneliti, penggunaan kohesi leksikal yang paling dominan pada teks eksposisi siswa kelas X SMKN 2 Medan adalah Repetisi (pengulangan) dengan jumlah persentase $38,46 \%$ atau 50 dari 130 dan penggunaan kohesi leksikal pada teks eksposisi siswa kelas X SMKN 2 Medan yang paling sedikit digunakan adalah hiponim dengan jumlah persentase 2,31\% atau 3 dari 130 penggunaan kohesi leksikal.

\section{Pembahasan Hasil Penelitian}

\section{Jenis Kohesi Leksikal dalam Teks Eksposisi Siswa SMKNegeri 2 Medan Tahun Pembelajaran 2016/2017}

Berdasarkan hasil penelitian penggunaan kohesi leksikal dalam teks eksposisi siswa kelas X SMKN 2 Medan terdiri dari repetisi, sinonim, antonim, hiponim, kolokasi dan ekuivalensi. Penggunaan repetisi terdiri dari ulangan penuh, ulangan dengan bentuk lain, ulangan dengan penggantian, sinonim terdiri dari sinonim mutlak, sinonim semirip, sinonim selingkung, antonim terdiri dari antonim mutlak, antonim kutub, antonim hierarkial, dan antonim majemuk.

\section{Penggunaan Kohesi Leksikal Pada Teks Eksposisi Siswa Kelas X SMKN 2 Medan} Tahun Pembelajaran 2016/2017

1) Ketepatan Penggunaan Kohesi Leksikal Pada Teks Eksposisi Siwa Kelas X SMKNegeri 2 Medan.

1. Repetisi (pengulangan)

a. Ulangan Penuh

Adapun data tentang ulangan penuh pada penelitian ini adalah sebagai berikut.

(1) Pendidikan merupakan senjata ampuh untuk mengubah dunia, karena pendidikan merupakan sarana dimana kita bisa mempelajari banyak hal yang sangat bermanfaat. (Hamdan Syukri Pulungan)

Pada data (1) diatas termasuk repetisi yaitu pengulangan penuh karena terdapat pengulangan kata pendidikan. 
b. Ulangan dengan bentuk lain

Adapun data tentang ulangan dengan bentuk lain pada penelitian ini adalah sebagai berikut.

(2) Setiap guru yang mengajar dikelasku merasa nyaman sehingga proses belajar mengajar menjadi lancar karena suasana dikelasku bersih karena kelasku bersih, indah dan sejuk sehingga membuat guru dan siswa merasa nyaman dikelas (Chairuman Arga Nababan)

Dari data (2) diatas dapat disimpulkan bahwa data tersebut adalah pengulangan dengan bentuk lain karena kalimat pertama dan kalimat kedua diulang padahal sebenarnya pengertian kalimat tersebut sama, yaitu sama- sama mengatakan bahwa proses belajar mengajar dikelasku terasa nyaman karena kelasku bersih.

c. Ulangan dengan Penggantian

Adapun data tentang ulangan dengan penggantian pada penelitian ini adalah sebagai berikut.

(3) Saya sekolah di medan, tepatnya di SMKNegeri 2 Medan yang beralamat di jl. STM Medan amplas. Ada beberapa alasan mengapa saya memilih bersekolah disana. (Wiliam Josua)

Pada data (3) diatas terdapat repetisi yaitu ulangan dengan penggantian yaitu penggantian kata SMKNegeri 2 Medan menjadi disana yang berarti kata disana juga memiliki arti yang menyatakan SMKNegeri 2 Medan.

2. Sinonim (Padan Kata)

a) sinonim mutlak

Adapun data tentang sinonim mutlak pada penelitian ini adalah sebagai berikut.

(4) Kegiatan ekstrakurikuler adalah kegiatan pendidikan diluar matapelajaran dan pelayanan konseling untuk membantu pengembangan peserta didik sesuai kegiatan, kebutuhan, potensi, bakat dan minat siswa. (Jetro Calvin)

Pada data (4) diatas terdapat penggunaan jenis kohesi leksikal yaitu sinonim mutlak yaitu pada kata potensi dan bakat, dimana kata tersebut merupakan kata yang maknanya sama.

b) Sinonim semirip

Adapun data tentang sinonim semirip pada penelitian ini adalah sebagai berikut.

(5) Guru-guru disekolahku sangat ramah dan pintar mendidik dan mengajari siswa atau murid yang ada disekolah. (Bayu Rahman) 
Pada data (5) diatas terdapat penggunaan kohesi leksikal yaitu penggunaan sinonim semirip pada kata siswa dan murid karena kata tersebut masih memiliki makna yang sama yaitu pelajar.

c) Sinonim selingkung

Adapun data tentang sinonim selingkung pada penelitian ini adalah sebagai berikut.

(6) Kelasku sangat nyaman sehingga guru yang mengajar jadi nyaman dan murid pun merasa tentram, nyaman dan aman (Chairuman Arga M. Nababan)

Pada data (6) diatas terdapat sinonim yaitu sinenom selingkung yaitu kata tentram dan nyaman masih memiliki makna yang sama.

3. Antonimi (lawan kata)

a) antonim mutlak

Adapun data tentang antonim mutlak pada penelitian ini adalah sebagai berikut.

(7) Biasanya kegiatan ekstrakurikuler diadakan setelah kegiatan belajar mengajar disekolah. (Jetro Calvin)

Pada data (7) terdapat penggunaan antonim mutlak yaitu terdapat pada kata belajar yang antonim atau lawan katanya adalah mengajar.

b) Antonim kutub

Adapun data tentang antonim kutub pada penelitian ini adalah sebagai berikut.

(8) Setiap guru yang mengajar dikelasku jadi nyaman dalam proses belajar mengajar, karena kelasku bersih, indah dan sejuk dan murid dikelasku menjadi nyaman dalam belajar. (Chairuman Argha M. Nababan)

Pada data (8) diatas merupakan penggunaan antonim kutub yaitu terletak pada kata guru dan murid.

c) Antonim hierarkial

Adapun data tentang antonim hierarkial pada penelitian ini adalah sebagai berikut.

(9) Pendidikan disekolahku tergolong pendidikan yang berkembang karena disana sudah mengggunakan kurikulum 2013, sedangkan pendidikan disekolah lain masing menggunakan kurikulum tingkat satuan pendidikan. (Marudut Harianja)

Pada data (9) diatas menggunakan antonim heararkil yang terdapat dalam kalimat, yang ditandai dengan kata sedangkan yang berarti membandingkan antar sekolah.

d) Antonim majemuk

Adapun data tentang antonim majemuk pada penelitian ini adalah sebagai berikut. 
(10)Dalam proses pembelajaran kami belajar dengan rapi, kami duduk dengan rapi di kelas dan guru yang mengajar duduk didepan kelas. (Cahirumam Arga M Nababan)

Pada data (10) diatas menggunakan antonim majemuk yang ditandai dengan kalimat kami duduk di kelas dan guru duduk di depan kelas.

\section{Hiponim}

Adapun data tentang hiponim pada penelitian ini adalah sebagai berikut.

(11)Pelajaran bahasa Indonesia termasuk salah satu pelajaran yang di UANkan dari pelajaran lain seperti pelajaran matematika, bahasa inggris, dan pelajaran kejuruan sehingga pelajaran bahasa Indonesia harus dibuat lebih dari 2 jam. (Aldi Akbar)

Pada data (11) diatas terdapat penggunaan jenis kohesi leksikal hiponim yaitu penggunaan hiponim yaitu pelajaran matematika, bahasa inggris, dan pelajaran kejuruan merupakan hiponim dari pelajaran yang di UANkan. Karena pelajaran yang di UANkan merupakan bagian dari atau penjabaran dari pelajaran matematika, bahasa inggris, dan pelajaran kejuruan.

\section{Kolokasi atau sanding kata}

Adapun data tentang kolokasi pada penelitian ini adalah sebagai berikut.

(12) Remaja adalah masa yang dialami oleh anak-anak pada saat SMP masa ini merupakan masa transisi dimana dimulai dari umur 10 hingga 21 tahun. (Fitra Ariansyah)

Pada data (12) diatas terdapat penggunaan kolokasi atau sanding kata karena disana terdapat pemilihan kata yang digunakan secara berdampingan untuk menghubungkan suatu kalimat yaitu kata merupakan dan kata dimana

6. Ekuivalensi (kesepadanan).

Adapun data tentang ekuivalensi pada penelitian ini adalah sebagai berikut.

(13) Kebersihan lingkungan sekolah adalah hal yang tidak bisa dipisahkan dari kegiatan disekolah dan merupakan faktor yang sangat penting dalam suasana belajar dikelas. (Abdul Syafii)

Pada data (13) diatas terdapat ekuivalensi atau kesepadanan yaitu pada kalimat Kebersihan lingkungan sekolah adalah hal yang tidak bisa dipisahkan dari kegiatan disekolah 
dan merupakan faktor yang sangat penting dalam suasana belajar dikelas. Kalimat ini merupakan kesepadanan yaitu kebersihan lingkungan sekolah tidak bisa dipisahkan dari kegiatan sekolah sepadan dengan faktor yang sangat penting dalam suasana dikelas. Penggunaan ekuivalensi ini tepat karena penggunaan tersebut sesuai dengan aspek leksikal bahasa.

2) Ketidaktepatan Penggunaan Kohesi Leksikal Pada Teks Eksposisi Siswa Kelas X SMKN 2 Medan Tahun Pembelajaran 2016/2017

1) Repetisi (pengulangan)

Ketidaktepatan penggunaan repetisi merupakan penggunaan kohesi leksikal repetisi yang tidak sesuai dengan tata bahasa. Berikut contoh ketidaktepatan penggunaan repetisi.

(14) Jurusan kontruksi bangunan adalah sebuah jurusan yang sangat jarang dijumpai pada sekolah -sekolah teknik padahal menurut saya jurusan ini sangat banyak lapangan-lapangna kerjanya dan sangat banyak yang membutuhkan orang-orang lulusan jurusan ini, dan sangat banyak pula orang- orang yang berhasil atau langsung bekerja setelah lulus jurusan ini. (Anggi Prayoha Siregar)

Pada data (14) diatas terdapat ketidaktepatan penggunaan kohesi leksikal repetisi ulangan penuh yakni penggunaan kata berulang-ulang yang membuat makna dari kalimat tersebut sulit ditemukan.

2) Kolokasi atau sanding kata

Ketidaktepatan penggunaan kolokasi merupakan penggunaan kohesi leksikal kolokasi yang tidak sesuai dengan tata bahasa. Berikut contoh ketidaktepatan penggunaan kolokasi.

(15)Pada masa remaja merupakan masa sulit karena butuh pengendalian diri yang lebih daripada masa anak-anak, dalam masa ini remaja butuh orang dewasa untuk mengarahkan ke perlakuan positif. (Fitra Ariansyah)

Pada data (15) diatas terdapat ketidaktepatan penggunaan kohesi leksikal hiponim hal itu terjadi akibat kesalahan dalam pemilihan kata sehingga membuat kalimat tidak padu dan maknanya sulit untuk dimengerti 
3) Ekuivalensi (kesepadanan).

Ketidaktepatan penggunaan ekuivalensi merupakan penggunaan kohesi leksikal ekuivalensi yang tidak sesuai dengan tata bahasa. Berikut contoh ketidaktepatan penggunaan ekuivalensi.

(16)Pendidikan merupakan cara untuk mengubah dunia karena dengan pendidikan kita bisa mengetahui dan mempelajari dunia. (Feri Andika)

Pada data (16) diatas terdapat ketidaktepatan penggunaan ekuivalensi, hal itu terjadi karena kalimat tersebut belum setara atau sejajar.

\section{Penggunaan Kohesi Leksikal Yang Paling Dominan Pada Teks Eksposisi Siswa Kelas X SMKN 2 Medan Tahun Pembelajaran 2016/2017}

Berdasarkan hasil penelitian yang telah dilakukan, penggunaan kohesi leksikal dalam teks eksposisi siswa kelas X SMKN 2 Medan yang paling dominan adalah repetisi (pengulangan) dengan jumlah persentase 38,46\% atau 50 dari 130 dan penggunaan kohesi leksikal pada teks eksposisi siswa kelas X SMKN 2 Medan yang paling sedikit digunakan adalah hiponim dengan jumlah persentase 2,31\% atau 3 dari 130 penggunaan kohesi leksikal leksikal pada teks eksposisi siswa kelas X SMKN 2 Medan yang paling sedikit digunakan adalah hiponim dengan jumlah persentase $2,31 \%$ atau 3 dari 130 penggunaan kohesi leksikal

\section{PENUTUP}

Berdasarkan hasil penelitian dan pembahasan mengenai analisis Penggunaan Kohesi Leksikal Pada Teks Eksposisi Siswa Kelas X SMKN 2 Medan Tahun Pembelajaran 2016/2017 dapat disimpulkan bahwa

1. Penggunaan Kohesi Leksikal dalam Teks Eksposisi Siswa Kelas X SMKN 2 Medan Tahun Pembelajaran 2016/2017 berjumlah 130 yang terdiri dari repetisi, sinonim, antonim, hiponim, kolokasi dan ekuivalensi.

2. Penggunaan kohesi leksikal dalam teks eksposisi siswa kelas X SMKN 2 Medan terdiri dari ketepatan dan ketidaktepatan. Ketepatan penggunaan kohesi leksikal terdiri dari ketepatan penggunaan repetisi 88,41\% atau 154 dari 130 jumlah keseluruhan kohesi leksikal dan ketidaktepatan kohesi leksikal terdiri dari repetisi, hiponim, kolokasi dan ekuivalensi dengan jumlah 11,59\% atau 19 dari 130 jumlah keseluruhan penggunaan 
kohesi leksikal. Dari data kualitatif tersebut, ketepatan penggunaan kohesi leksikal pada teks eksposisi siswa kelas X SMKNegeri 2 Medan termasuk dalam kategori Sangat Baik.

3. Penggunaan kohesi leksikal dalam teks eksposisi siswa kelas X SMKN 2 Medan Tahun Pembelajaran 2016/2017 yang paling dominan adalah repetisi (pengulangan) dengan jumlah persentase 38,46\% atau 50 dari 130 dan penggunaan kohesi leksikal pada teks eksposisi siswa kelas X SMKN 2 Medan yang paling sedikit digunakan adalah hiponim dengan jumlah persentase 2,31\% atau 3 dari 130 penggunaan kohesi leksikal.

\section{DAFTAR PUSTAKA}

Barus, sanggup.2010. Pembinaan Kompetensi Menulis. Medan: USU press.

Halliday, M.A.K \& Hasan, R. 1976. Cohesion in English. London: Longman.

Mahsun. 2013. Teks Dalam Pembelajaran Bahasa Indonesia. Jakarta: PT Raja Grafindo Persada

Sumarlam, dkk.2003. Teri dan Praktik Analisis Wacana. Solo :Pustaka Cakra Surakarta.

Syamsuddin. 2009. Metode Penelitian Kualitatif. Jakarta: PT Raja Grafindo Persada 